\title{
KAMPUNG NELAYAN BERKELANJUTAN DI KAMAL MUARA
}

\author{
Henry Yonanda ${ }^{1)}$, Rudy Trisno ${ }^{21}$
}

1) Program Studi S1 Arsitektur, Fakultas Teknik, Universitas Tarumanagara, henry.yonanda@gmail.com 2) Program Studi S1 Arsitektur, Fakultas Teknik, Universitas Tarumanagara, rudyt@ft.untar.ac.id

\begin{abstract}
Abstrak
Generasi milenial dianggap sebagai generasi yang akan melakukan perubahan nyata terkait dengan pemanasan global. Akan tetapi, beberapa studi pun menunjukan bukti bahwa generasi millenial justru memiliki kesadaran serta kepekaan yang tidak lebih tinggi dibandingkan dengan generas-generasi sebelumnya. Pada satu sisi, bumi kian melakukan perubahan yang begitu derastis. Berbagai macam kerusakan pun terjadi dalam berbagai jenis yang menjadi generator dari perubahan iklim yang drastis ini. Nelayan sebagai salah satu profesi yang menggantungkan nasibnya pada lautan, kian terganggu dengan kondisi ini. Hal ini menyebabkan kerusakan pada rumah-rumah di kawasan pesisir pantai. Kampung kota di Jakarta, sebagai permukiman terpadat di daerah urban menjadi salah satu kenerator utama pada suatu kota. Dengan segala karakteristiknya yang berbanding terbalik dengan perkotaan, kampung kota merupakan bagian yang tidak dapat dipisahkan dari suatu kota. Eksistensi suatu kampung telah menjadi embrio dari perkembangan kota Jakarta. Jakarta merupakan salah satu kota pesisir terbesar di dunia. Daerah pesisir dari kota ini telah menjadi generator ekonomi utama dari kota itu sendiri dan juga nasional. Keberadaan kampung nelayan di Jakarta pun menjadi salah satu program penting yang perlu mendapatkan perhatian. Maka dari itu, proyek ini bertujuan untuk menciptakan suatu komunitas kampung pesisir yang berkelanjutan, adaptif serta memiliki ketahanan terhadap kenaikan permukaan air laut yang terjadi. Metode perancangan pada proyek ini dibagi menjadi 2 bagian utama yaitu analisis mikro yang membahas mengenai tipe dan perilaku, serta analisis makro yang membahas proyek dari segi perancangan urban. Dengan menitik beratkan pada studi perilaku, dan melakukan riset mendalam terhadap transformasi tipologi yang terjadi pada kampung, desain ini diharapkan dapat menjadi suatu arketipe untuk pengembangan kampung di daerah pesisir di masa depan di seluruh Indonesia. Sehingga dapat disimpulkan, bahwa dengan adaptasi tipe, perilaku serta sistem berkelanjutan yang sesuai dan tepat, desain dari kampung nelayan berkelanjutan ini dapat menjadi suatu respon yang tepat dalam menjawab permasalahan yang terjadi di kampung-kampung pesisir.
\end{abstract}

Kata kunci: adaptif; arketipe; berkelanjutan; kampung nelayan; kenaikan permukaan air laut

Abstract
Millennials have been touted as the generation that will do something about global warming.
Conversely, some social scientists studying generational differences have found evidence that
younger generations are less likely to engage in civic matters like environmental activism. Lack
of civic engagement among Millennials may reduce their likelihood of engaging in collective
action on global warming. On the other hand, the world is drastically changing. Within the
recent years, climate change has become a growing concern worldwide. The various modes of
destruction imposed on the environment are targeted to be the catalyst to these changes.
According to climate scientists, sea level rise is one of the most important impacts of global
climate change. Fishermen as one of the professions that depend their life on the sea, is
affected so much by this condition. This condition might destroy their houses on the coastal
area. Urban Kampong in Jakarta as the most dense human settlements in urban area has
become one of the main economic generator for a city. With all the contradict characteristics
and forms, urban kampongs are the part of the city that cannot be separated from one to
another. The existence of kampong has become the main embryo of the development of
Jakarta. Jakarta is one of the biggest coastal city in the world. The coastline of this city has
become the main economic generator for the coty and the nations. The existence of
fishermen's kampong in Jakarta has also become an essential program for the city, in order to
fullfill the needs of fresh catch of sea products. Therefore, The project is aimed to create a
sustainable and adaptive coastal kampong community, that has the resilience to the rising sea
level. By concerning on the kampong's behaviour, and doing research of the typological


transformation of the kampong, the design is also expected to serve as an archetype fot the future development of endagered coastal settlements all across the country. several sustainable approach and behaviourial approach are also injected in this project to create a contextual design that would help the kampong to grow, and adapt to all the conditions, and situation in the future.

Keywords : adaptive; archetype; fishermen's kampong; sustainable; rising sea level

\section{PENDAHULUAN}

Generasi Millenial seringkali disebut-sebut sebagai generasi yang akan melakukan suatu perubahan besar terhadap perubahan iklim dan pemanasan global yang terjadi di dunia. Dewasa ini, kampanye sosial maupun politik seringkali memberikan gagasan kuat bahwa generasi muda lebih cenderung bertindak atas perubahan iklim dibandingkan dengan generasi yang lebih tua. Akan tetapi, beberapa ilmuwan sosial telah menemukan beberapa bukti bahwa generasi millenial justru kurang memiliki keterlibatan sosial, kegelisahan, dan aksi nyata terkait perubahan iklim yang terjadi saat ini, dibandingkan dengan generasi yang lebih tua (Twenge, J,. Campbell, K,. and Freeman, E., 2012). Kondisi ini menjadi hal yang cukup memprihatinkan bagi generasi millenial, mengingat generasi ini merupakan populasi terbesar saat ini.

Dunia mulai berubah secara drastis. Dengan kenaikan temperatur global, langit diatas kota diselimuti asap polusi, dan melelehnya bongkahan es yang menandakan meningkatnya permukaan laut menjadi beberapa contoh yang mengkhawatirkan bagi dunia sekarang ini (Williams, 2009). Meskipun kondisi dan kehancuran yang kini dialami telah meresahkan kualitas kehidupan miliyaran orang di seluruh dunia, hal ini bisa saja menjadi awalan dari kerusakan yang lebih besar di masa yang mendatang. Hal demikianpun perlu menjadi perhatian utama bagi kota-kota pesisir, salah satunya adalah Kota Jakarta. Sebagai Ibukota Negara Indonesia, Jakarta merupakan salah satu kota pesisir terbesar di panet ini, dengan populasi penduduk yang melebihi 10, 18 juta pada 2015, ditambah dengan sekitar 2,5 juta komuter harian dari area sub-urban, dan total luas wilayah $662 \mathrm{~km} 2$. Tingkat pertumbuhan populasi di Jakarta mencapai 2,19\% per tahunya selama periode 2000-2010 (Badan Pusat Statistik, 2010), menjadikan Jakarta salah satu kota terpadat di dunia, dan diperkirakan kota ini akan mencapai 30 juta penduduk pada tahun 2030. Sebagai konsekuensi dari perkembangan pesat ini Jakarta telah menghadapi banyak masalah pembangunan kota, salah satu hal yang memprihatinkan ialah penurunan muka tanah (land subsidence) yang masalah utamanya disebabkan oleh ekstraksi air tanah yang berlebihan. Secara khusus, penggunaan air tanah untuk kegiatan industri yang begitu banyak menjadi pendorong laju penurunan muka tanah yang cepat. Penurunan muka tanah di Jakarta ini juga menjadi salah satu faktor utama terjadinya banjir di Jakarta, di samping faktor-faktor penyebab lainnya.

Daerah pesisir Jakarta menjadi area yang paling rentan terhadap terjadinya banjir. Menurut Intergovernmental Panel on Climate Change 5th Assessment Report (IPCC AR5), banjir pesisir atau coastal floods cenderung menjadi hal yang umum di wilayah pesisir di seluruh dunia karena konsekuensi dari perubahan iklim di masa depan, termasuk kenaikan permukaan laut (Sea Level Rise) dan faktor-faktor lain seperti peningkatan populasi, urbanisasi, dan penurunan tanah.

Kampung sebagai struktur pemukiman informal dan padat ditinggali oleh $60 \%$ penduduk kota Jakarta. Seringkali, kampung-kampung di Jakarta terdapat pada daerah rawan banjir dan terdiri dari keluarga-keluarga berpendapatan rendah, sehingga membuat penampilan fisik perumahan dan infrastruktur kampung menjadi sangat kumuh dan dibawah standar kelayakan. Upaya-upaya telah dilakukan pemerintah dalam merelokasi, dan merevitalisasi kampungkampung di Jakarta. Akan tetapi, langkah ini belum diterapkan sepenuhnya di seluruh kampung karena adanya berbagai pro dan kontra yang timbul diantara penduduk dan pemerintah. Khususnya dalam proposal ini, menyangkut daerah pesisir Jakarta yang rentan terhadap banjir pesisir, kampung pesisir atau kampung nelayan menjadi perhatian utama yang akan dibahas. Sesuai dengan namanya, kampung nelayan didominasi oleh penduduk dengan 
mata pencaharian utama yaitu memancing. Melihat data bahwa jumlah nelayan saat ini didominasi oleh generasi millenial, kehidupan nelayan di pesisir Jakarta amsih dianggap belum layak memenuhi standar. Perubahan iklim, kenaikan permukaan laut dan pasang surut air laut menjadi permasalahan utama yang menyebabkan menurunnya pendapatan para nelayan setiap tahunnya. Dengan terjadinya hal ini, migrasi dan peralihan profesi pun menjadi solusi jangka pendek terbaik bagi para penduduk kampung nelayan di Jakarta. Hal ini menjadi kondisi yang cukup memprihatinkan tanpa adanya solusi yang tepat.

Berlandaskan hal-hal diatas, proposal perancangan ini mencoba mengadopsi proyek "Sustainable and Resilient Fishermen Kampong" yang memiliki ketahanan terhadap kenaikan permukaan laut dan independensi terhadap pusat kota sehingga menjadi suatu solusi yang relevan dalam menanggapi perubahan iklim, dan migrasi penduduk yang terjadi di Kota Jakarta.

Proyek "Sustainable and Resilient Fishermen Kampong" bertujuan untuk meningkatkan ketahanan kampung nelayan di daerah pesisir Jakarta terhadap perubahan iklim dan kenaikan permukaan laut.Penelitian ini juga bertujuan untuk menyusun alternatif strategi desain prototipe untuk agar dapat digandakan dan dimodifikasi dapat menjadi sampel untuk pengembangan Kampung kota di daerah pesisir serta menginjeksi sistem berkelanjutan sehingga kampung nelayan memiliki independensi terhadap pusat kota.

Ruang lingkup pembahasan pada proyek yang dilakukan dibatasi dalam pembahasan teoritis dan analitis yang dilatar belakangi dengan konteks "Tipe, Perilaku, dan Kesejamanan dalam Arsitektur" sebagai tema besar tugas akhir yang diangkat. Hal-hal diluar ilmu arsitektur dan urban akan dibahas seperlunya guna memberikan informasi yang menunjang dan mendukung proyek.

\section{MATERIAL}

\section{Karakteristik Nelayan}

Nelayan buruh merupakan mata pencaharian yang memerlukan kondisi fisik yang baik. Pada umumnya nelayan buruh berusia relatif muda sehingga memungkingkan fisik dan kondisi kesehatan yang masih baik. Berikut merupakan tabel data yang diambil terhadap 85 nelayan yang dikelompokan berdasarkan rentang umur. Tingkat umur nelayan terbesar di Kampung Kamal Muara berada pada interval umur 30-39 tahun dengan jumlah nelayan sebesar 42 orang atau $49,412 \%$. Sedangkan distribusi responden menurut tingkat umur nelayan terkecil berada pada umur $>59$ tahun dengan jumlah nelayan sebesar 3 orang atau 3,529\%.

Dengan mengacu pada pengertian generasi millenial diatas, dapat dilihat bahwa sekitar $60 \%$ profesi nelayan didominasi oleh generasi millenial saat ini. Dari beberapa hasil studi menunjukkan bahwa masyarakat nelayan merupakan salah satu kelompok masyarakat yang secara intensif dilanda kemiskinan. Kemiskinan tersebut disebabkan oleh faktor-faktor kompleks yang saling terkait serta merupakan sumber utama yang melemahkan kemampuan masyarakat dalam membangun wilayah dan meningkatkan kesejahteraan sosialnya (Sipahelut, 2010). Kemiskinan yang dialami masyarakat nelayan juga dilatar belakangi oleh kurangnya modal dan teknologi yang dimiliki para nelayan, rendahnya akses pasar dan rendahnya partisipasi masyarakat dalam pengolahan sumber daya alam. Selain itu, ada juga penyebab lain yaitu faktor sosial seperti pertumbuhan jumlah penduduk yang tinggi, rendahnya tingkat pendidikan, dan rendahnya tingkat kesehatan serta alasan lain seperti sarana dan prasarana umum di wilayah pesisir (Prakoso, 2013).

Mengingat Negara Indonesia merupakan negara dengan luas laut terbesar, kita memiliki potensi untuk memanfaatkan hal tersebut demi kesejahteraan khususnya masyarakat nelayan. Namun, realitanya masyarakat belum mampu meningkatkan hasil produksi mereka, bahkan profesi sebagai nelayan cenderung identik dengan kemiskinan. Tingkat kesejahteraan para pelaku perikanan (nelayan) pada saat ini masih dibawah sektor-sektor lain, termasuk sektor pertanian agraris. Nelayan (khususnya nelayan buruh dan nelayan tradisional) merupakan 
kelompok masyarakat yang dapat digolongkan sebagai lapisan sosial yang paling miskin diantara kelompok masyarakat lain di sektor pertanian. Ditambah lagi dengan belum optimalnya kebijakan-kebijakan dari pemerintah yang cenderung lebih berorientasi kearah pengembangan sektor daratan.

\section{Zoning Eksisting Pada Tapak Perancangan}

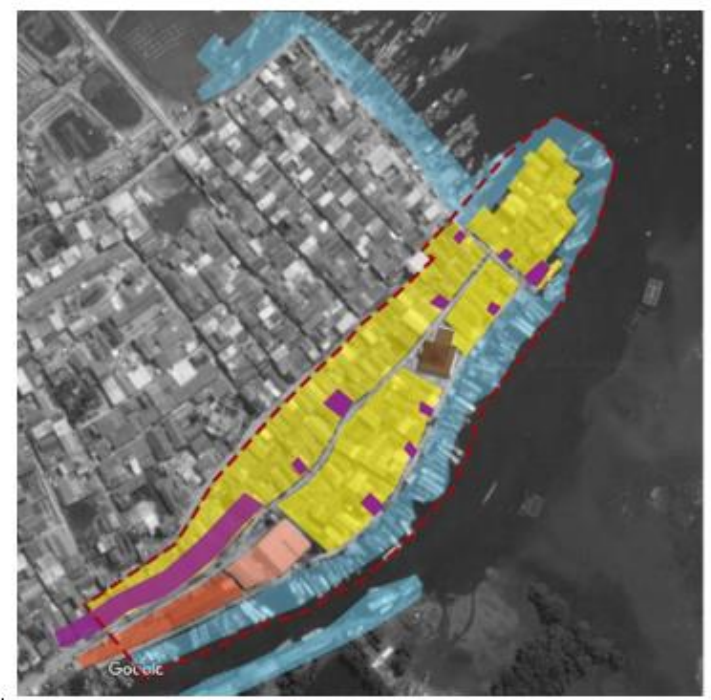

Zona Permukiman

Kampung

Zona Dermaga

Kapal Nelayan

Zona Tempat

Pelelangan Ikan

Zona Pasar Ikan

Zona Tempat

Ibadah dan Ruang

Publik

Gambar 1. Diagram Zonasi Eksisting Kampung Kamal Muara Sumber: Penulis, 2019

Setelah melakukan survey lapangan, Kampung Kamal Muara memiliki program-program fungsional bangunan yang sangat bervariasi didalam struktur kampungnya. Seperti yang dapat dilihat pada Gambar 2.2, Kampung Kamal Muara memiliki 5 fungsi program utama yaitu antara lain zona permukiman, zona dermaga kapal nelayan, zona pelelangan ikan, zona pasar ikan, zona tempat ibadah dan ruang terbuka, serta zoa warung dan pertokoan.

\section{Analisis Kampung Kamal Muara}

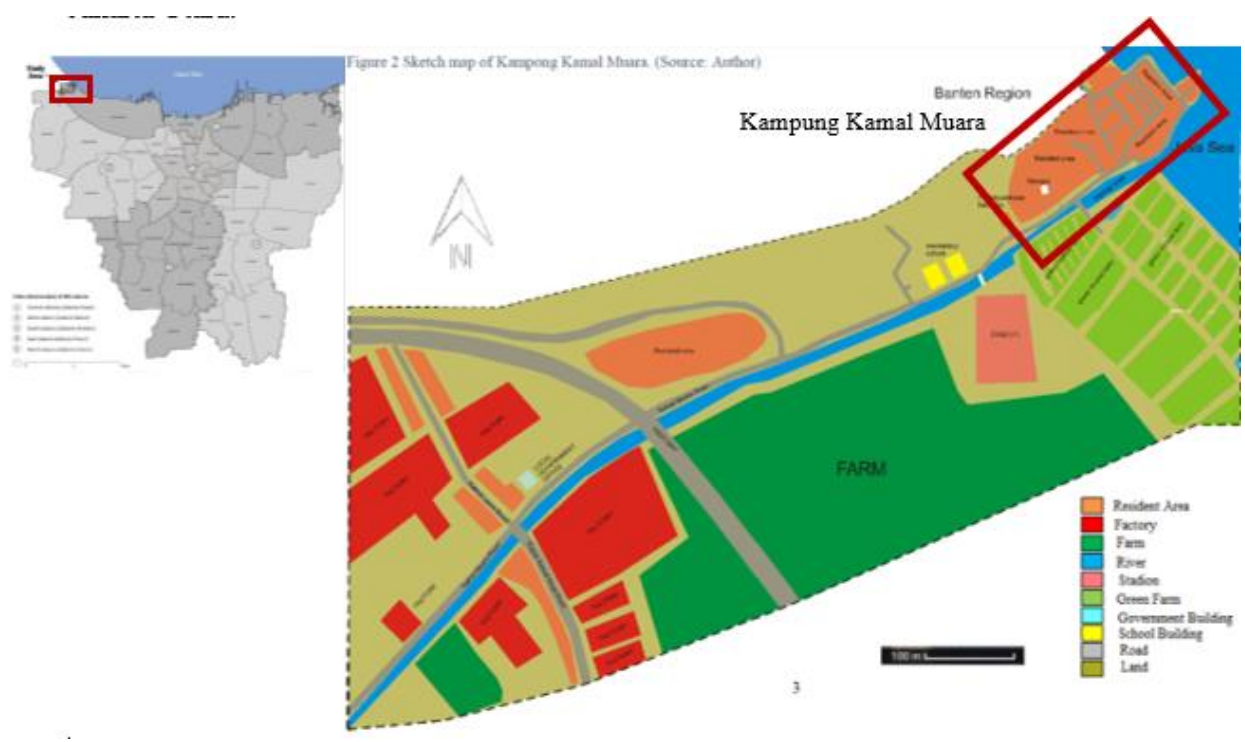

Gambar 2. Sketch Map Lokasi Kampung Kamal Muara

Sumber: Rini Mayasari, University of Wakaito, 2016

(Community Risilience of People of Kampong Kamal Muara, North Jakarta, Indonesia) 
Kampung Kamal Muara adalah salah satu kampung di Jakarta. Kampung ini terletak di Kecamatan Penjaringan, Jakarta Utara, Kampung Kamal Muara adalah desa asli suku Betawi yang telah menetap selama lebih dari 60 tahun di wilayah pesisir. Kampung ini memiliki populasi 1.480 rumah tangga (Simarmata, 2015). Penangkapan ikan adalah mata pencaharian utama bagi komunitas ini. Akan tetapi, beberapa penduduk kampung sudah mulai bekerja di kawasan industri di dekat kampung tersebut, dan di sektor lapangan kerja informal lainnya, karena penurunan pendapatan perikanan. Banjir menjadi ancaman terbesar bagi kehidupan warga di Kampung Kamal Muara. Kampung ini mulai mengalami banjir yang signifikan pada bulan November 2002. Baru-baru ini, ketinggian air banjir semakin tinggi dan intensitas banjir telah meningkat secara signifikan sejak 2012. Kini frekuensi banjir meningkat secara signifikan menjadi 3-4 kali lipat, jika dibandingkan dengan dulu. Sebagai upaya pencegahan bencana, pemerintah Jakarta membangun tanggul pada akhir 2012. Sebagai hasil dari upaya mitigasi ini, tanggul tersebut mengurangi besarnya banjir meskipun frekuensinya masih tetap (Simarmata, 2015). Kondisi ini berkaitan langsung dengan perubahan iklim yang berpengaruh secara langsung ke daerah pesisir Jakarta Utara. Kenaikan permukaan laut dan perubahan iklim, telah diproyeksikan bahwa dengan fenomena pasang laut yang tinggi, kenaikan permukaan laut dan penurunan tanah, sekitar $25 \%$ dari populasi Jakarta akan sangat dipengaruhi oleh genangan dari laut dalam 15 tahun ke depan, dan tentu saja, wilayah yang paling terkena dampaknya adalah Jakarta Utara.

Data mengenai kawasan Kampung Kamal Muara diambil dari pengaturan zonasi fungsi kawasan berdasarkan TPZ DKI Jakarta. Kampung Kamal Muara terletak di Kecamatan Penjaringan, Jakarta Utara. Berikut merupakan peta zonasi dari Kecamatan Penjaringan.

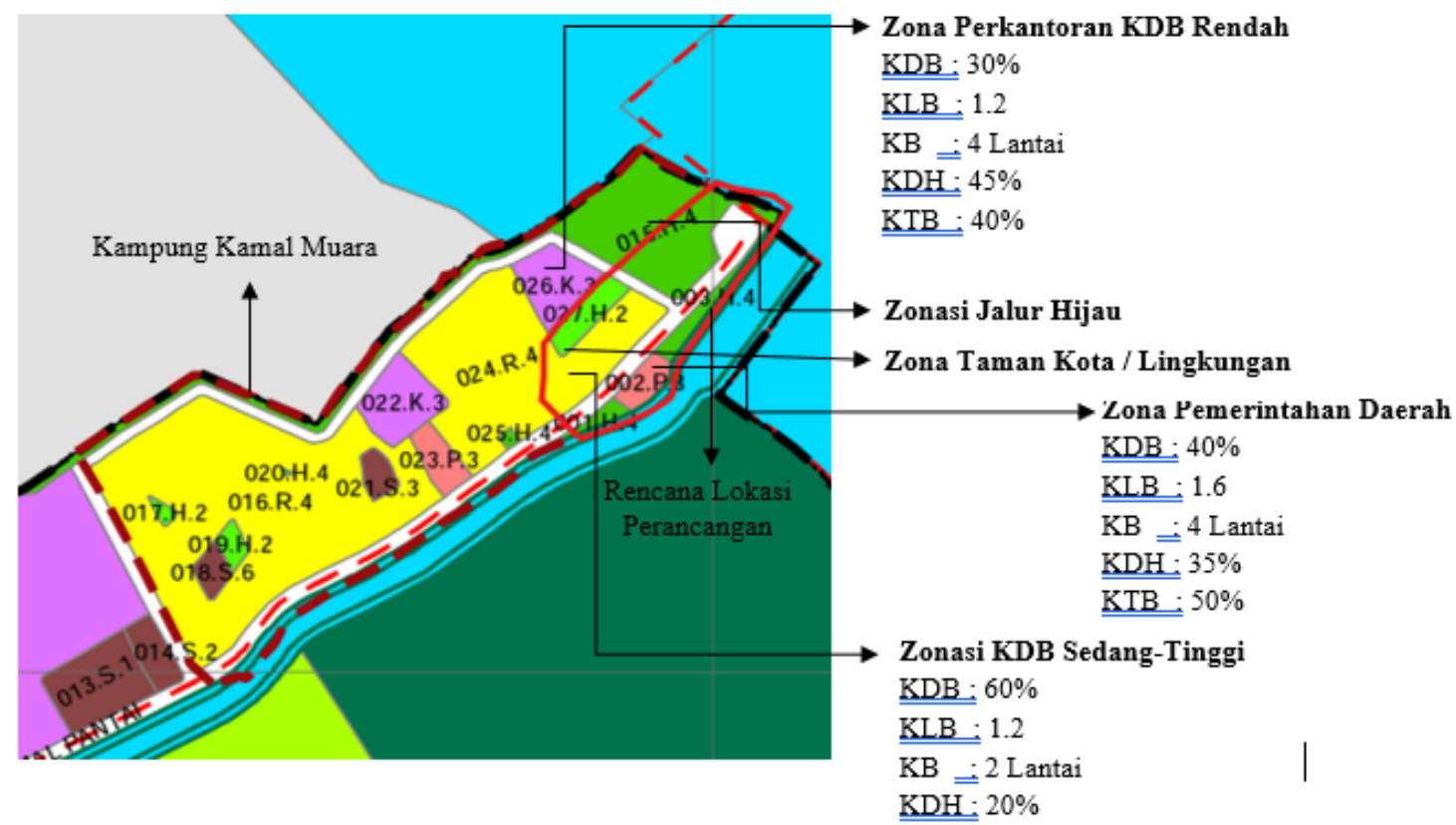

Gambar 3. Zonasi Fungsi di Kampung Kamal Muara

Sumber: www.tataruang.jakarta.go.id

\section{KAJIAN LITERATUR}

\section{Type and Behavior}

Sebagai tema besar dari tugas akhir ini, perlu dilakukan pemahaman mendalam mengenai "Type and Behaviour". Dalam memahami tema tersebut, perlu dilakukan studi terhadap dua elemen penting didalamnya yaitu Type (Tipe) dan Behaviour (Perilaku) sehingga keduanya dapat dipahami sebagai satu kesatuan yang positif. 
Type

Terdapat beberapa pemahaman dan ekspresi yang ditemukan dalam beberapa tulisan mengenai tipe dan arsitektur. Menurut Quatremere de Quincy, tipe mewakili ide elemen yang seharusnya berfungsi sebagai aturan untuk suatu model (Quincy, 1825). Menurut G.C. Argan, Tipe harus dimengerti sebagai "the interior strucure of a form". Rafael Moneo pun mendefiniskannya sebagai konsep yang mendeskripsikan suatu grup objek dengan karakter struktur formal yang sama. Secara etimologi, kata tipe berasal dari bahasa latin yaitu typus yang berarti suatu pola ataupun suatu jenis. Pada interpretasi penulis-penulis ini, type dapat diartikan juga sebagai ide, bentuk dan struktur (Madrazo, 1995).

Gagasan tipe, sebagai hukum atau prinsip yang menjelaskan bagaimana bentuk-bentuk dihasilkan sehingga membekali setiap elemen dengan signifikansi simbolis, memperoleh kehadiran yang cukup besar di antara para ahli teori arsitektur jaman pencerahan (Enlightenment). Dalam artikel 'Type', yang ditulis Quatremere de Quincy untuk volume ketiga Encyclopedie, 1825, tipe selanjutnya menyiratkan bentuk karakteristik dari fisiognomi tertentu yang memungkinkan bangunan dibaca sesuai tujuan fundamentalnya. Tipe digunakan tidak hanya untuk menunjukkan pencarian asal-usul tetapi untuk mengatur semua jenis produksi yang berbeda dalam arsitektur dengan mengekspresikan karakteristik umum dan fisiognomi khusus mereka. Seiring berjalannya waktu, memiliki hubungan mendasar antara arsitektur dan masyarakat dalam pandangan sejarah yang abstrak dan fleksibel membuat gagasan tentang tipe lebih berperan untuk memahami jenis evolusi dalam arsitektur.

Tipe merupakan alat otonom aktif dalam desain arsitektur, dan itu adalah ide di balik gambar yang ditransfer kepada pengamat. Dalam praktek nyatanya, teori mengenai tipe digunakan untuk dapat memahami, dan menganalisis dalam arsitektur. Teori mengenai tipe juga menjadi penghubung yang kuat antara tipologi dan revolusi arsitektur dalam sejarah. Konsep-konsep turunan mengenai tipe juga menjadi pengetahuan penting dalam pengklasifikasian selama proses perancangan. Konsep turunan tipe yang pertama ialah tipe bangun yang muncul dan dilatar belakangi oleh suatu trend dan perubahan yang terjadi di suatu tempat, yang disebut sebagai Proto-tipe. Kedua ialah Stereo-tipe mengacu pada tipe bangun yang paling sering dipakai terhadap suatu wujud fungsional suatu bangunan. Archetipe mengacu pada bentuk ideal berdasarkan suatu variabel yang didasari oleh kebutuhan atau esensi utama fungsi bangunan.

\section{Behaviour}

Perilaku / Behaviour adalah setiap tindakan seseorang yang dapat dilihat atau didengar. Perilaku harus didefinisikan dengan cara yang dapat diamati dan diukur sehingga setiap orang yang bekerja dengan anak tersebut memiliki pemahaman yang baik tentang seperti apa perilaku itu dan terdengar (Paul A. Alberto \& Anne C. Troutman, 2006). Perilaku juga diartikan sebagai suatu aksi dan reaksi organisme terhadap lingkungannya, hal ini berarti bahwa perilaku baru akan terwujud bila ada sesuatu yang diperlukan untuk menimbulkan tanggapan yang disebut rangsangan, dengan demikian maka suatu rangsangan tertentu akan menghasilkan perilaku tertentu pula. Manusia dan perilakunya adalah bagian dari sistem yang menempati tempat dan lingkungan yang tidak dapat dipisahkan secara empiris. Maka dari itu, perilaku manusia selalu terjadi pada suatu tempat dan dapat dievaluasi secara keseluruhan tanpa pertimbangan faktor-faktor lingkungan.

\section{Type and Behaviour}

Dengan melihat pengertian dari keduanya, dapat dilihat bahwa tipe sebagai suatu alat pengklasifikasian suatu struktur formal, memberikan informasi mengenai perbedaan struktur yang terbentuk akibat terciptanya perbedaan perilaku didalamnya. Melihat tipe secara historis juga membawa hasil analisis yang menunjukan transformasi arsitektur yang didasari oleh perubahan perilaku, baik perilaku manusia, maupun alam yang terus berubah seiring perkembangan jaman. Tipe dan perilaku menjadi kedua hal yang sangat lekat dan tidak 
terpisahkan dalam arsitektur. Keduanya dapat mempengaruhi satu sama lain guna melahirkan suatu wujud arsitektur yang progresif dan responsif.

\section{Type and the City}

Jika urbanisasi berkaitan dengan perluasan pemukiman manusia yang didorong terutama oleh ekonomi, kota di sisi lain adalah pemukiman terkonsolidasi dan terkonsentrasi yang mendahului terjadinnya urbanisasi. biasanya dirusak oleh tembok kota dan titik konsentrasi untuk orang-orang dan kegiatan, menghasilkan masyarakat yang bertingkat yang secara fungsional berbeda dan secara politis terpecah (Kostof, 1999). Kota adalah produk historis dan berpusat pada fungsi sipil dan simbolis dari pemukiman dan koeksistensi manusia. Gagasan kota dapat diwujudkan dalam tipe dominannya, mengkomunikasikan gagasan kota sebagai respons terhadap kondisi historis dan sosiokultural tertentu. Bangunan sebagai elemen permanen pada kota dapat bertindak sebagai tempat pembuktian tipologis dari sejarah, konstruksi, dan bentuk kota (Rossi, 1982). Maka dari itu, menurut Rossi, untuk memahami tipe adalah untuk memahami kota itu sendiri. Pier Vittorio Aurell dalam bukunya yang berjudul "City as Political Form : Four Archetypes of Urban Transformation" mengatakan bahwa instrumentalitas paradikmatik archetype dasar arsitektural (architectural archetype) sebagai alat tata kelola yang luas dan menurutnya, evolusi kota dapat dianggap sebagai evolusi tipe pada kota.

\section{Pengertian Kampung}

Kampung diartikan sebagai salah satu unit dasar kota. Secara etimologis kata kampung terkait dengan kata compound, dimana pada abad-14 kata ini berarti suatu kumpulan dari kombinasi variasi bentuk. Kampung sering kali mengandung spektrum keberagaman etnis dan tingkat pendapatan. Dengan menelusuri sejarah kampung yang merupakan bagian penting dari citranya, kampung dipahami sebagai pemukiman bersama yang muncul begitu saja, dan bukan merupakan bagian dari suatu perencanaan dalam suatu kota. Definisi kampung juga kerap kali mengacu pada suatu ketidakberaturan atau kesemrawutan. Penempatan lahan-lahan pada struktur suatu kampung biasanya tidak teratur baik dalam bentuk maupun ukurannya, dan rumah-rumah pun dibangun sendiri oleh penduduk setempat. Pada akhir abad ke-19, Pemerintah Kolonial Hinda Belanda menjadikan kampung sebagai identitas yang terpisah dari kota. Hal ini yang menyebabkan kampung sebagai komunitas menjadi terpisah dari unsur modernitas (Rabani, 2010). Esensi kampung mengandung unsur-unsur yang unik sehingga membentuk kompleksitas. Kampung juga seringkali dianggap sebagai lanskap kota, karena pertumbuhannya yang organik, yang dipengaruhi oleh perubahan kondisi lingkungan sekitar, sehingga kampung pun membentuk suatu pola jaringan yang organik.

\section{Kampung Nelayan}

Kampung nelayan merupakan daerah pemukiman yang dihuni oleh mayoritas penduduk yang bekerja sebagai nelayan. Wilayah tersebut memiliki perbedaan yang cukup signifikan jika dibandingkan dengan kampung pada umumnya, karena aktivitas pergerakan, dan sosial budaya yang terjalin didalamnya membuat kampung memiliki ciri khasnya tersendiri. Sejauh ini, kampung nelayan tidak memiliki sarana dan prasarana yang cukup memadai untuk menopang komunitas didalamnya. Menurut Kementrian Pekerjaan Umum, Karakteristik kampung nelayan adalah kawasan hunian yang terdiri dari unit-unit perumahan yang memiliki beragam sarana dan prasarana yang menunjang kehidupan dan mata pencaharian penghuninya, serta berbatasan langsung dengan perairan. Karakteristik yang juga menjadi salah satu ciri utama dari suatu kampung ialah kehadiran suatu gang, atau koridor yang memiliki banyak peranan penting dalam keberlangsungan suatu kampung. Koridor merupakan suatu manifestasi dari kebersamaan, interaksi sosial, ruang penunjang, serta pemberi keamanan dan kenyamanan bagi para warga (Lianto, Arifin, \& Dwisusanto, 2017). 60\% dari 
populasi suatu kampung nelayan adalaah nelayan, dan pekerjaan lainnya yang terkait dengan pengolahan dan jual-beli ikan (Artiningrum, 2017). Pada masa ini, dengan berbagai faktor perubahan iklim yang terjadi, kampung nelayan di daerah pesisir menjadi sangat rentan terhadap kenaikan permukaan air yang terjadi. Tanpa adanya adopsi tipe yang tepat, struktur suatu kampung tidak akan memiliki ketahanan terhadap permasalahan yang akan terjadi terkait banjir pesisir, dan kenaikan permukaan laut.

\section{Teori Metabolisme}

Arsitektur Metabolisme merupakan suatu gerakan arsitektur Jepang yang lahir pada saat Japan World Design Conference 1960. Gerakan ini dipimpin oleh Kenzo Tange sebagai mentor dan Kisho Kurokawa sebagai pemimpin gerakan kemudian Kiyonori Kikutake dan Fumihiko Maki sebagai anggota-anggotanya. Gerakan ini melihat bahwa arsitektur maupun kota di masa yang akan datang harus di rencanakan dengan waktu yang cepat, mudah dan dapat diganti secara periodik menggunakan teknologi yang maju dan memudahkan manusia untuk mengontrol lingkungannya. Metabolis menganggap arsitektur dan kota sebagai jasad hidup yang kapabel dalam bereaksi terhadap berbagai tingkat perubahan yang terjadi (Lin, 2010). Salah satu tujuan dari grup ini adalah memperkembangkan suatu building system yang dapat mengatasi masalah-masalah di dalam kehidupan masyarakat yang selalu berubah-rubah dengan cepat dan pada saat yang sama melestarikan tata kehidupan yang sudah mantap /stabil.

Gerakan metabolisme juga berperan sebagai bagian dari teori arsitektur yang bertujuan memecahkan persoalan akibat tingginya jumlah penduduk, dan semakin sesaknya kota Jepang selama pertumbuhan ekonomi yang pesat pada waktu itu, juga sebagai sebuah teori kritis terhadap analisa sosial dalam sudut pandang arsitektur (Pernice, 2004). Gerakan ini berusaha menghubungkan antara kebudayaan Jepang dan arsitektur kontemporer melalui pembauran dan selanjutnya mentransformasikan tatanan nilai barat menghasilkan model yang cocok untuk tradisi budaya Jepang. Kelompok ini memiliki maksud untuk menghasilkan suatu sistem yang membuat manusia menjaga kontrol atas teknologi (Pernice, 2004).

Teori metabolisme pun memiliki beberapa karakteristik yang menjadi titik berat pertimbangan sebagai landasan utama dari gerakan ini. Berikut merupakan beberapa karakteristik ataupun ciri-ciri utama dari teori Metabolisme.

\section{Organicity of Urban Design}

Arsitek-arsitek dan desainer metabolis mempercayai dan meilihat kota dan bangunan suatu entitas yang tidak statis, melainkan sebagai suatu struktur organik yang terus berganti layaknya suatu metabolisme biologis. (Lin, 2010).

\section{Megastructure}

Gerakan Metabolisme juga merupakan suatu bagian dari gerakan arsitektur Megastructure yang ditulis oleh Reyner Banham. Megastructure pada konteks metabolisme mengacu pada suatu strategi urban desain yang bertujuan untuk mengelompokan program pada suatu kota kedalam suatu struktur tunggal (Lin, 2010). Hal ini dilihat oleh Fumihiko Maki sebagai suatu hal yang sangat mungkin direalisasikan pada perkembangan teknologi yang terjadi pada masa tersebut.

\section{Organic Growth and Change}

Yang menjadi akar dari gerakan Metabolisme mengacu pada pemikiran tentang 'kota sebagai suatu proses'. Terinspirasi dari perkembangan pesat suatu kota dan karakteristik suatu kota modern yang kian berubah secara tidak terduga, gerakan Metabolisme memikirkan menganai konsep suatu kota yang memiliki pola yang dapat terus menerus relevan seiring berkembangnya jaman. Pola ini menjadi satu-satunya guideline dari perkembangan kota yang organik dimasa depan (Lin, 2010). 


\section{Expansion and Contraction Based on Need}

Konsep adaptif juga menjadi salah satu poin penting yang menjadi gagasan utama dari gerakan metabolisme. Melihat suatu gagasan struktur masif yang akan terus digunakan dari waktu ke waktu, sistem bongka-pasang, dan duplikasi dianggap sebagai salah satu cara yang paling efektif dalam menjaga keberlanjutan dan perkembangan suatu bangunan metabolis. Melihat perkembangan dari gaya hidup dan juga kebutuhan ruang, kebutuhan-kebutuhan ini akan kian bertambah dan berkurang seiring berkembangnya zaman (Lin, 2010).

\section{METODE}

Metode desain pada perancangan ini menitik beratkan pada studi mengenai tipe dan perilaku yang didasari oleh studi tipologi sebagai studi mikro, serta penerapan metode desain dari teori metabolisme oleh Kenzo Tange, yang mencoba melihat desain suatu kampung secara makro. Untuk dapat merealisasikan desain kampung ini, metode perancangan dibagi menjadi 2 proses utama, yaitu :

1) Proses mikro yang mencoba menganalisis kegiatan di Kampung Kamal Muara, serta studi tipe kampung nelayan, yang nantinya menghasilkan rancangan tipe yang sesuai dengan studi yang telah dilakukan.

2) Proses makro yang dilakukan dengan analisis evolusi permukiman Kampung Kamal Muara, dan aspek-aspek urban design yang berkorelasi dengan teori metabolisme.

\section{DISKUSI DAN HASIL}

\section{Analisis Mikro Kampung Kamal Muara}

Analisis Kegiatan di Kampung Kamal Muara

Sebelum masuk kedalam pembahasan program pada proyek ini, analisa kegiatan di dalam Kampung Kamal Muara pun dilakukan guna memberikan gambaran besar mengenai aktivitas, sirkulasi, dan program-program yang ada didalam kampung ini. Analisa kegiatan dilakukan dengan metode kolase dari dokumentasi keadaan eksisting pada Kampung Kamal Muara. Gambar 5.1 menjelelaskan visualisasi keseluruhan aktivitas, program, serta sirkulasi kegiatan yang ada di kampung ini pada waktu produktif kampung (5:00 - 12:00). Dari diagram kegiatan tersebut, dapat dilihat bahwa kampung ini terbagi kedalam beberapa program utama, yang menjadi generator berlangsungnya kehidupan penduduk di Kampung Kamal Muara. Untuk lebih detil, telah terlampir pada Lampiran 1 gambar keseluruhan diagram analisis kegiatan di Kampung Kamal Muara.

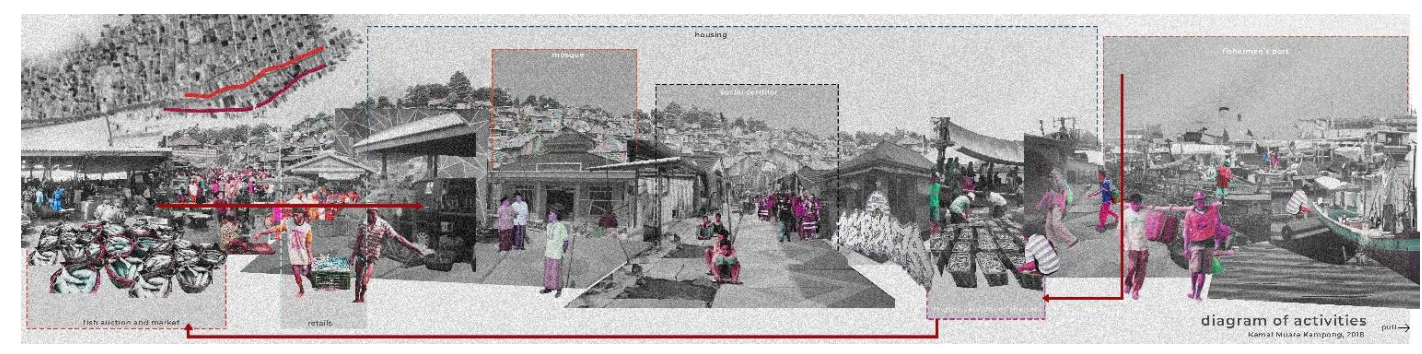

Gambar 4. Diagram Analisis Kegiatan Kampung Kamal Muara Sumber: Penulis, 2019

\section{Studi Tipe Hunian Kampung Nelayan}

Proses analisis dimulai dengan studi terhadap tipe dari permukiman itu sendiri. Studi ini dilakukan dengan mencari studi kasus dari 5 kampung nelayan bugis di seluruh indonesia, dan juga 5 proyek yang terkait dengan teori atau gagasan mengenai metabolisme. Analisis ini bertujuan mengidentifikasi suatu struktur hunian dari elemen terkecilnya yaitu satuan unit dari hunian sebagai elemen terkecil dari tipe. 
Dari studi mengenai tipe di bawah, beberapa studi kasus telah di bedah satu persatu, membahas dari elemen makro yaitu kawasan kampung itu sendiri, hingga sampai ke elemen terkecil yaitu elemen pembentuk ruang pada suatu unit hunian itu sendiri. Analisis ini mencoba mengambil sampel dr 3 jenis tipe sesuai dengan ukuran dan kapasitasnya sehingga dapat dijadikan sebagai alat pembanding satu dengan yang lainnya.

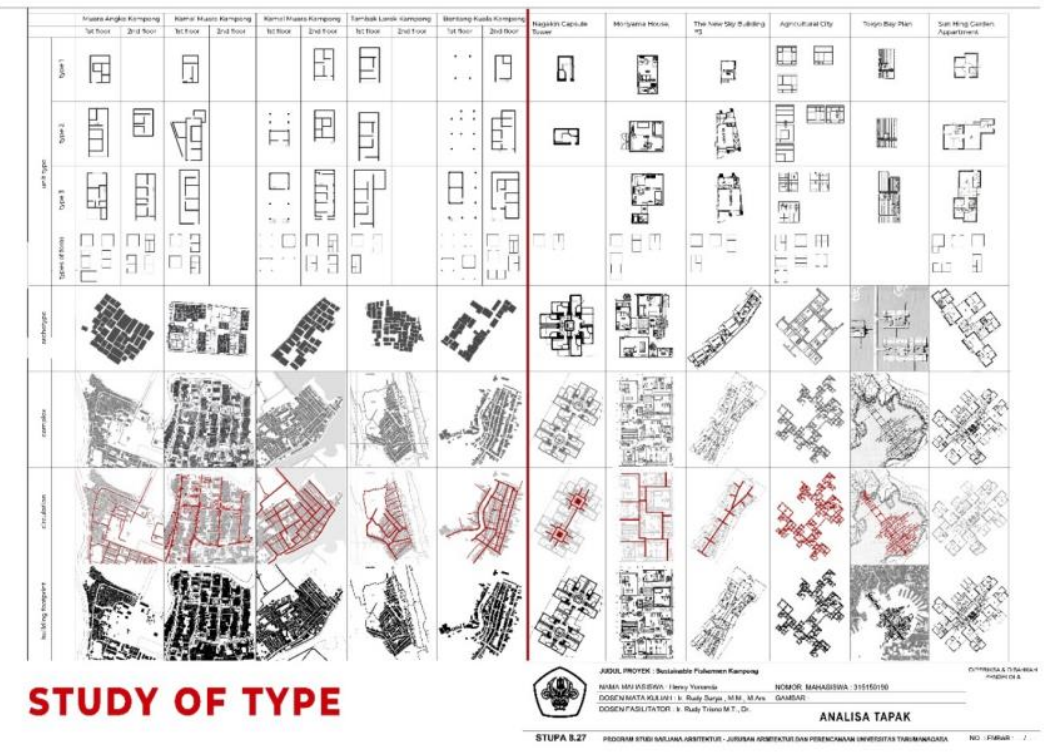

Gambar 5. Studi Tipologi

Sumber: Penulis, 2019

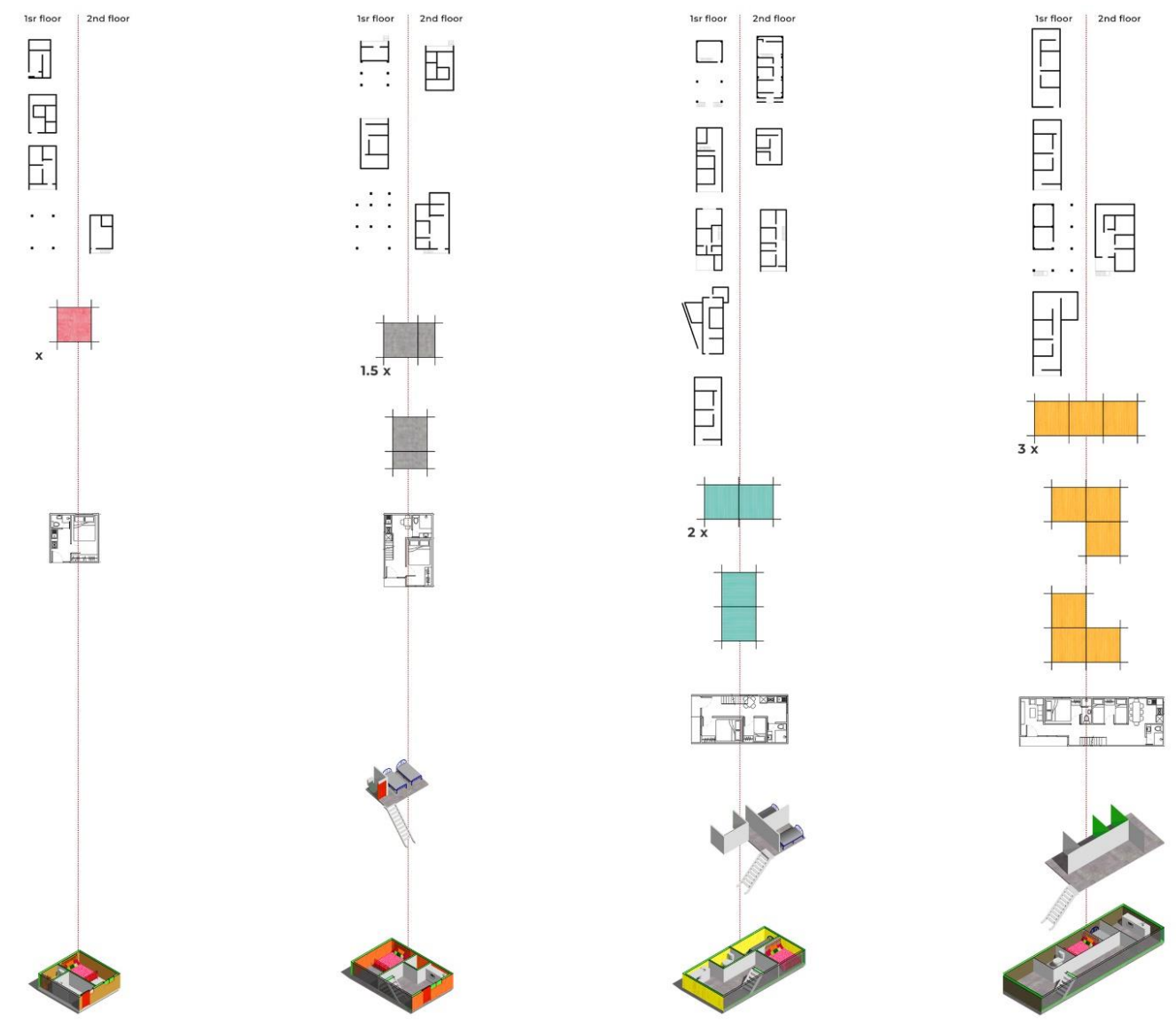

Gambar 6. Penglasifikasian dan Perancangan Unit Type Proyek Sumber: Penulis, 2019 
Setelah dilakukannya studi tipologi, beberapa studi kasus tersebut kemudian diklasifikasikan berdasarkan elemen pembentuk ruang, ukuran, dan okupansinya didalam beberapa kategori seperti yang dapat dilihat pada diagram dibawah ini.

Seperti yang dapat dilihat pada diagram diatas, unit-unit hunian dibagi menjadi 4 tipe sesuai luasan, okupansi dan elemen pembentuk ruang masing-masing dari tipe tersebut. Proses desain pun diawali dengan menentukan $x$ sebagai modul terkecil dari unit satuan hunian pada proyek ini. Perkembangan luasan pun diikuti dengan 3 luasan lain yaitu 1.5x, 2x, dan 3x sebagai unit terbesar. Keempat unit hunian ini menjadi langkah awal terbentuknya struktur kampung dari proyek ini.

\section{Analisis Makro Kampung Kamal Muara}

Analisis Evolusi Permukiman Kampung Kamal Muara

Membahas spesifik mengenai tipe dari suatu hunian, membawa analisis dari proyek ini pada hal yang paling mendasar, yaitu identifikasi rekam sejarah perkembangan permukiman di dunia. Dari melihat perkembangan sejarah dari evolusi permukiman ini, identitas, dan evolusi maupun mutasi yang terjadi pada tipe hunian dapat diidentifikasi dari akar permulaannya

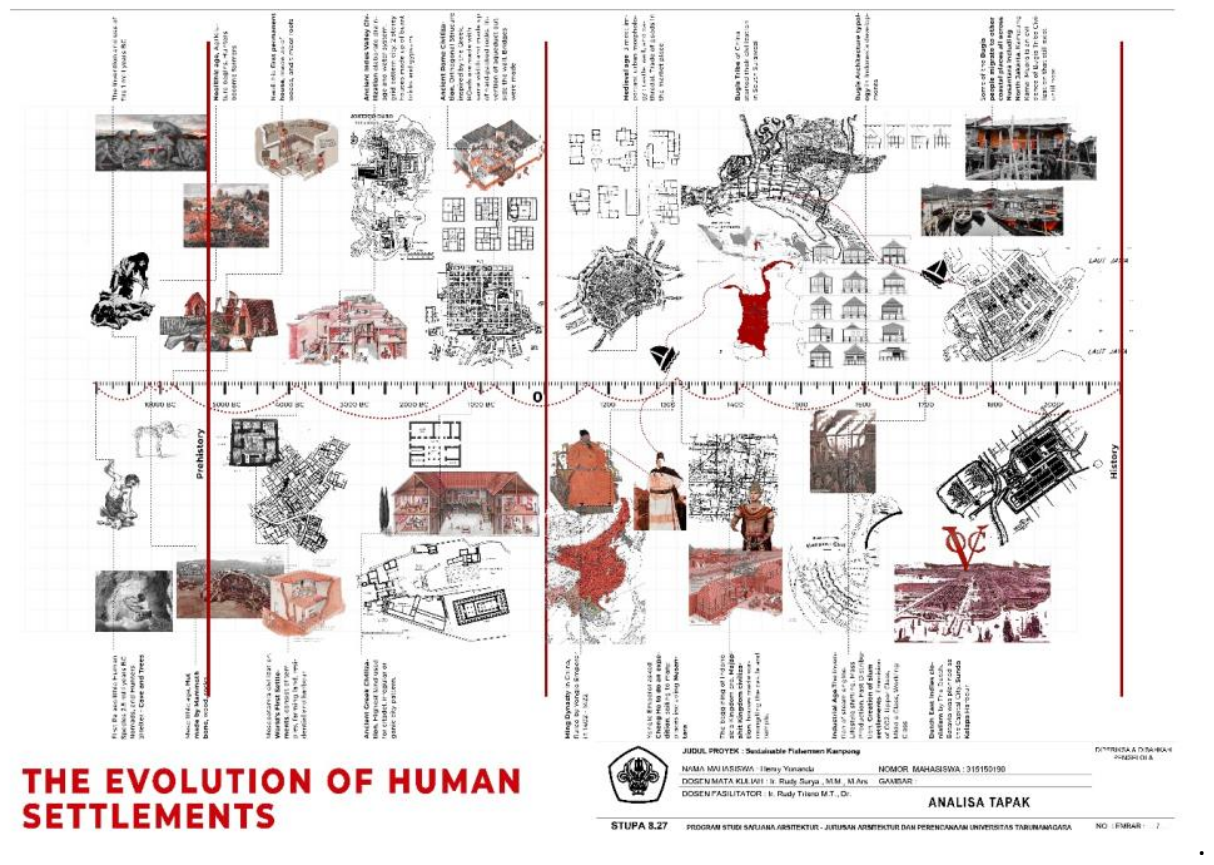

Gambar 7. Studi Evolusi Permukiman Manusia

Sumber: Penulis, 2019

Seperti yang terdapat pada diagram diatas, investigasi mengenai permukiman berawal dari masa pra sejarah, yang membahas mengenai kehidupan manusia purba yang bersifat nomaden, dan seiringnya waktu, hal ini terus berkembang hingga membahas mengenai permukiman pertama di dunia yaitu kehidupan permukiman di Mesopotamia. Perkembangan fungsi, dan teknologi dari suatu permukiman juga kian berkembang dari waktu ke waktu di berbagai belahan dunia. Perkembangan Kampung Kamal Muara pun berakar dari peradaban suku Bugis yang merupakan suku asli dari Cina, yang mulai masuk ke indonesia pada tahun 1400an.

\section{Urban Design}

1) Organicity of Urban Design

analisis mikro dilakukan dengan pendekatan metode yang diambil dari teori metabolisme mengenai studi dari jalan-jalan didalam dan disekitar tapak yang menekankan pada kualitas ruang suatu situasi urban. Analisis ini menekankan pada beberapa aspek penting yaitu outline kawasan, ketinggian bangunan, bukaan, elemen-elemen vertikal dan juga horizontal. Berikut merupakan diagram dari studi jalan-jalan disekitaran tapak Kampung Kamal Muara yang menggambarkan keorganikan pada perkembangan kampung 


\section{2) Megastructure}

Dalam menerapkan teori metabolisme kedalam proyek kampung ini, beberapa program dan unit tipe yang telah dirancang kemudian diprogramkan pada satu struktur tunggal yang mampu mengakomodir kegiatan suatu komunitas yang berisikan 12-15 kepala rumah tangga. Struktur ini nantinya akan berperan sebagai prototype dari proyek kampung ini.

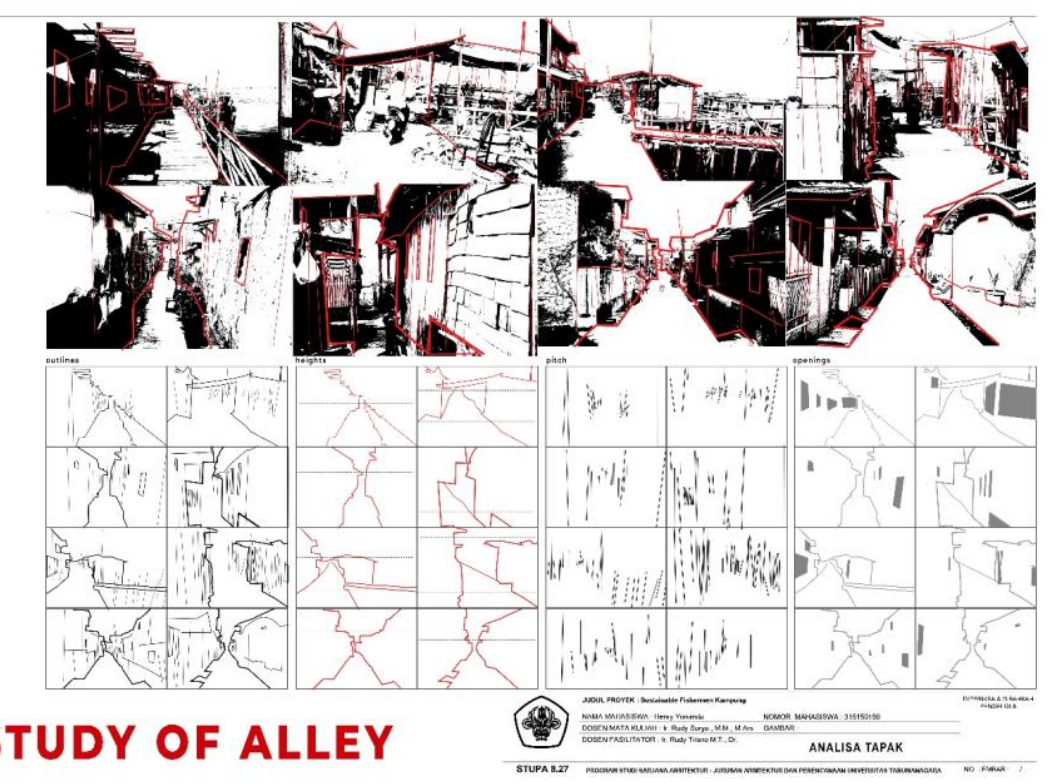

Gambar 8. Studi Jalan-jalan Sekitaran Tapak Kampung Kamal Muara Sumber: Penulis, 2019

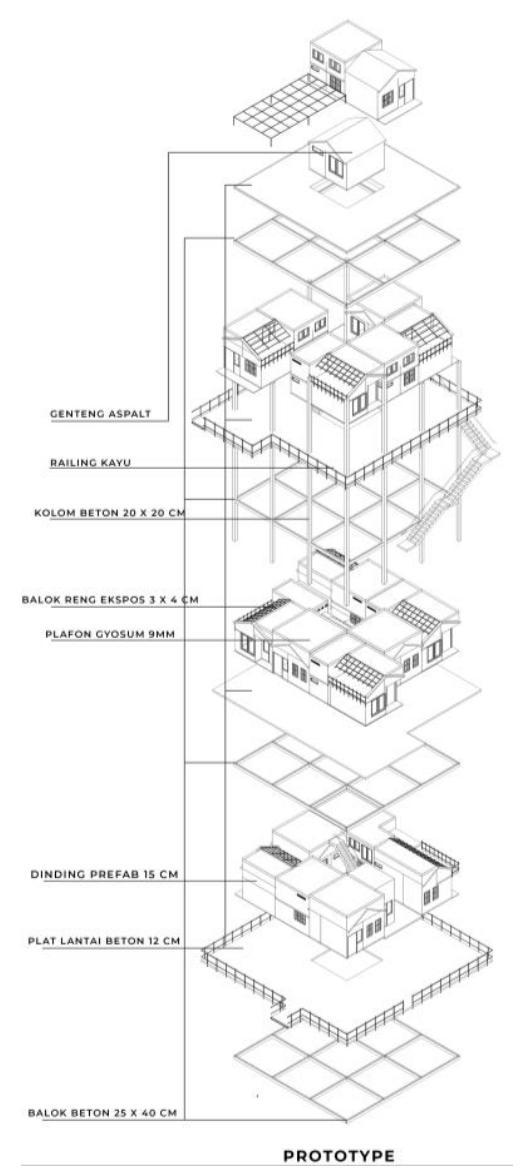

Gambar 9. Kampung Prototype Unit

Sumber: Penulis, 2019 


\section{3) Organic Growth and Change}

Pertumbuhan organik pada suatu kampung merupakan suatu karakteristik utama yang tidak dapat terlepas dan terhindarkan pada suatu kampung. Perancangan suatu kampung yang berkelanjutan dan adaptif ini juga berusaha menciptakan pola utama perkembangan sehingga nantinya, perkembangan pada suatu kampung di daerah pesisir pun dapat terjadi dengan organik melalui polapola yang telah dipertimbangkan sebelumnya. Perkembangan pada Kampung di daerah pesisir akan terjadi akibat pertumbuhan penduduk, dan juga kebutuhan ruang dari masyarakan didaerah pesisir. Dari prototype yang telah terbentuk, kumpulan dari beberapa prototype tersebut pun akan menciptakan suatu komunitas makro yang berisikan 90-120 kepala rumah tangga. Komunitas yang lebih besar ini juga berperan sebagai archetype dr proyek ini. Selain berisikan tower-tower hunian, satu archetype pun menyediakan taman terbuka hijau, area-area publik, lahan parkir, serta area-area servis yang mampu menampung kebutuhan satu komunitas tersebut. Archetype ini nantinya akan menjadi landasan utama dari duplikasi dan perkembangan dari proyek ini. Berikut merupakan ilustrasi denah dari satu archetype pada proyek kampung nelayan ini.

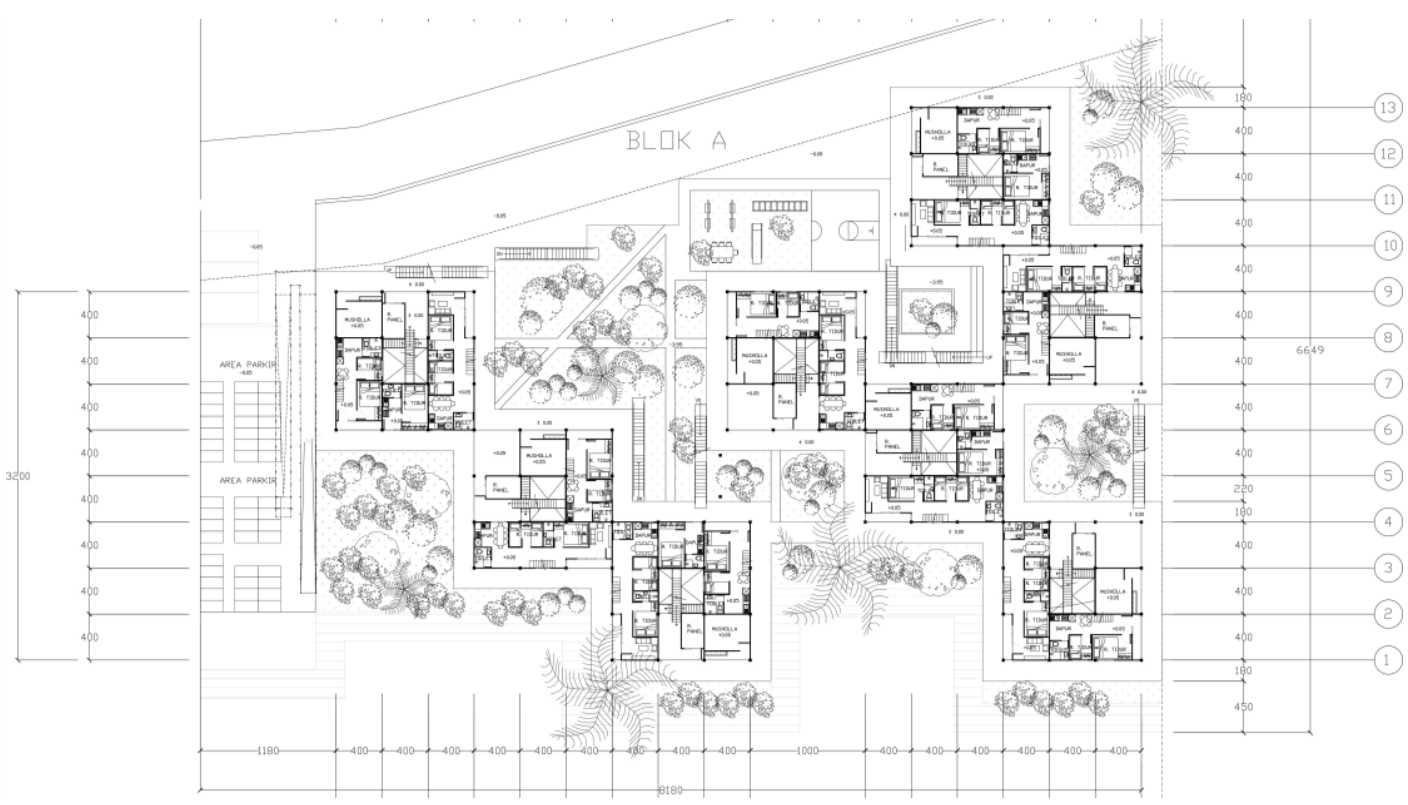

Gambar 10. Denah Arche

Sumber: Penulis, 2019

4) Expansion and Contraction Based on Need

Suatu perkembangan dan ekspansi yang terjadi akibat terjadinya penambahan jumlah penduduk, serta perubahan yang terjadi dengan begitu cepat juga menjadi aspek jangka panjang yang perlu dipertimbangkan. Teori metabolisme juga mencoba mengaplikasikan suatu sistem yang tepat dalam melakukan perkembangan dan kontraksi proyek di masa yang akan datang. Maka dari itu, pada proyek ini, archetype yang telah dirancang akan menjadi satuan unit yang akan menjadi dasar duplikasi dari proyek ini. Archetype telah dirancang dengan pertimbangan aspek-aspek pemenuhan kebutuhan untuk jumlah okupansi dalam satu archetype tersebut. Maka dari itu, dengan mempertimbangkan sistem ekspansi jangka panjang, desain ini diharapkan dapat menjadi salah satu contoh yang dapat diaplikasikan di daerah-daerah pesisir laut lainnya. 


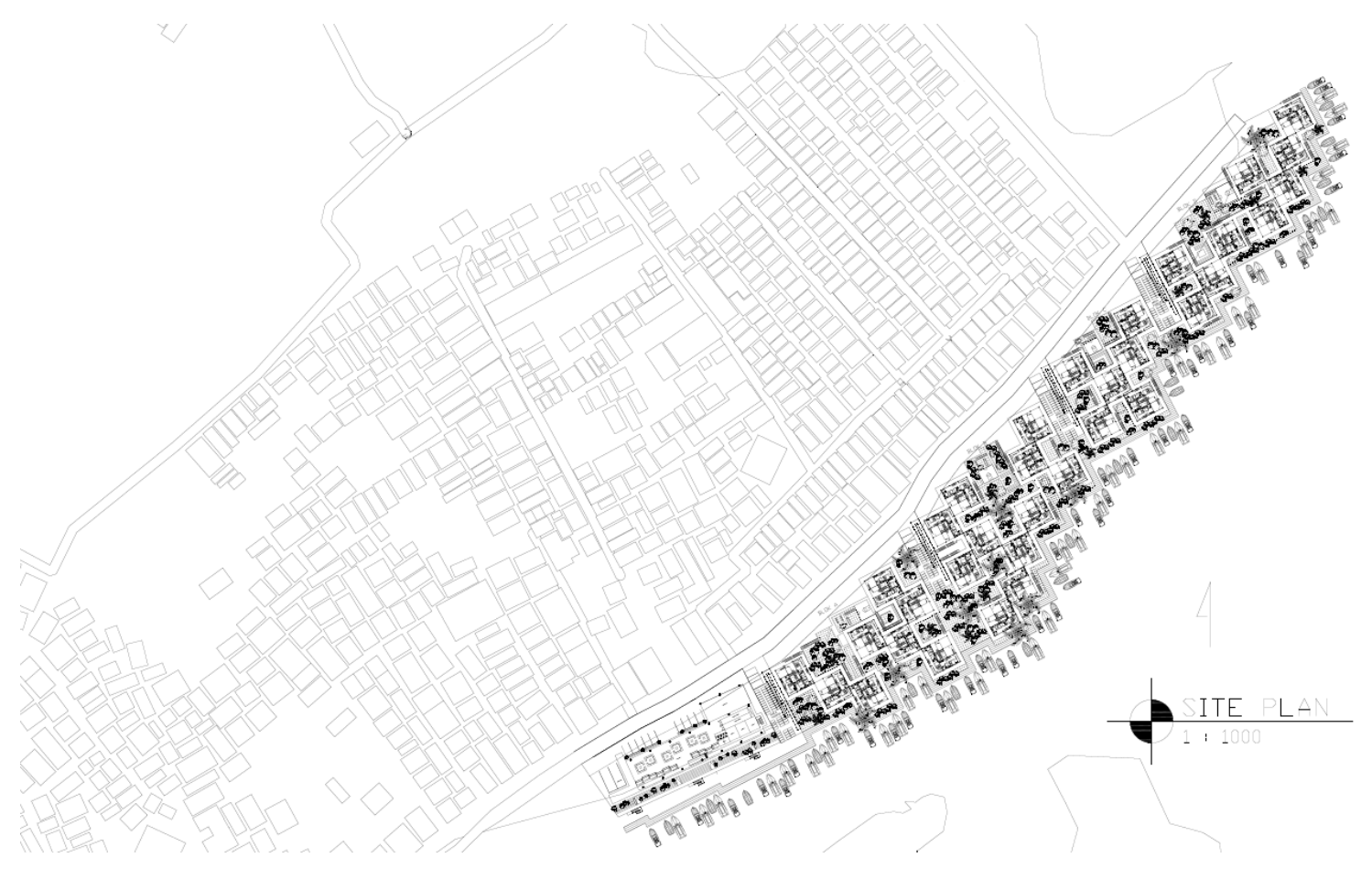

Gambar 11. Siteplan Proyek

Sumber: Penulis, 2019

\section{KESIMPULAN DAN SARAN}

Daerah pesisir utara jakarta, sebagai tempat dimana permukiman nelayan berada dan tempat dimana para nelayan menggantungkan nasibnya kini pun terancam oleh dampak perubahan iklim yang menyebabkan kenaikan permukaan laut. Dengan pendekatan tipologi dan morfologi yang tepat, proyek tugas akhir ini diharapkan dapat memberikan suatu solusi dari gambaran Kampung Nelayan Kamal Muara yang memiliki ketahanan terhadap kenaikan permukaan laut. Pengadopsian paradigma arsitektur berkelanjutan yang didasari dengan teori metabolisme oleh Kenzo Tange, juga menjadi salah satu elemen penting yang menjadi dasar dari pertumbuhan kampung ini di masa yang akan dayang sehingga kampung nelayan ini dapat menjadi tempat yang ideal bagi keberlangsungan hidup para generasi millenial, dan generasi-generasi yang akan datang.

Untuk selanjutnya, disarankan untuk meneliti lebih lanjut mengenai sistem attach and detach yang menjadi salah satu elemen penting dalam teori metabolisme yang dapat di aplikasikan kedalam struktur suatu kampung susun berkelanjutan.

\section{REFERENSI}

Architectenbureau Marlies Rohmer. (2011). ArchDaily. Retrieved from

https://www.archdaily.com/120238/floating-houses-in-ijburg-architectenbureau-marlies-rohmer Artiningrum, P. (2017). Adaptasi arsitektur vernakular kampung nelayan bugis di kamal muara.

Aurell, P. V. (2011). City as Political Form : Four Archetypes of Urban Transformation.

Dimmock, M. (2019). Defining generations: Where Millennials end and Generation Z begins.

Djaja, R., Rais, J., Abidin, Z.H., Wedyanto, K. (2004). "Land subsidence of Jakarta Metropolitan Area.

Henrique, K. P. (2014). Housing Responses to Climate Change: Analyzing Architectures of Transition in

Flood-prone Zones.

Hiroshi Takagi, Miguel Esteban, Takahito Mikami , dan Daisuke Fujii. (2016). Projection of coastal floods in 2050 Jakarta.

IPCC. (2007). Synthesis Report. IPCC.

IPCC. (2013). The Physical Science Basis. IPCC.

IPCC, Working Group I Report. (1996). The Science of Climate Change.

Kostof, S. (1999). City Shaped: Urban Patterns and Meanings Through History. 
Lianto, F., Arifin, L. S., \& Dwisusanto, Y. B. (2017). Role of Corridor in Territorial Meaning Formation in "Owned Low-Cost Apartments" ('Rusunami') Bidara Cina, Jakarta, Indonesia. International Journal on Advanced Science Engineering Indormation Technology.

Lin, Z. (2010). Kenzo Tange and the Metabolist Movement. New York: Routledge.

Madrazo, L. (1995). The concept of type in architecture.

Moneo, R. (1978). On Typology.

nArchitects. (2010). Retrieved from nArchitects: http://narchitects.com/work/moma-rising-currents/ Neufert, E. (1980). Architect's Data.

Paul A. Alberto \& Anne C. Troutman. (2006). Apllied behaviour analysis for teachers.

Pernice, R. (2004). Metabolism Reconsidered Its Role in the Architectural Context of the World. Journal of Asian Architecture and Building Engineering.

Prakoso, J. (2013). Peranan Tenaga Kerja, Modal dan Teknologi terhadap peningkatan pendapatan masyarakat nelayan di Desa Asemdoyong Kecamatan Taman Kabupaten Pemalang.

Quincy, Q. d. (1825). "Type' Encyclopedie vol. 3.

Rabani, J. A. (2010). Kampung Perkotaan: Kajian Historis-Antropologis atas Kesenjangan Sosial dan Ruang Kota.

Rossi, A. (1982). The Architecture of the City.

Simarmata, H. (2015, March). Measuring vulnerability : Lesson from vurnelable groups along the example of kampongs in North Jakarta. 4th Global Forum on Urban Resilience and Adaptation. Retrieved from http://resilientcities.iclei.org/fileadmin/sites/resilientcities/files/Resilient_Cities_2013_Candi_2.pdf

Sipahelut, M. (2010). Analisis Pemberdayaan Masyarakat Nelayan di Kecamatan Tobelo Kabupaten Halmahera Utara.

Twenge, J,. Campbell, K,. and Freeman, E. (2012). Generational differences in young adults' life goals, concern for others, and civic orientation.

Urban Green-Blue Grids. (2012). Urban Green-Blue Grids. Retrieved from https://www.urbangreenbluegrids.com/projects/amphibious-homes-maasbommel-the-netherlands/

Williams, E. (2009). Aquatecture: Architectural Adaptation to Rising Sea Levels. 
